\title{
PENGARUH PENGUNGKAPAN MANAJEMEN RISIKO TERHADAP ASIMETRIS INFORMASI DENGAN KUALITAS AUDIT DAN FUNGSI INTERNAL AUDIT SEBAGAI VARIABEL PEMODERASI
}

\author{
Budi Kurniawan \\ Universitas Bunda Mulia \\ Email : budikh@yahoo.com
}

\begin{abstract}
The study aims to test the influence of negative risk disclosure against information asymmetry and test the role of internal audit function and the specialization of auditors in strengthening the negative influence of risk disclosure against information asymmetry. The research samples consist of 281 companies listed on the Indonesia Stock Exchange (IDX) in 2016. The method of analysis used in this research is the method of regression analysis of moderating by using STATA analysis tool version 13. The results showed that the disclosure of risk has a negative and significant effect on information asymmetry, while internal audit functions and auditors ' specializations cannot strengthen the negative influence of risk disclosure against asymmetry Information.
\end{abstract}

Keywords: Disclosure, information asymmetry, internal audit function, specialisation of Auditors

\begin{abstract}
Abstrak: Penelitian ini bertujuan untuk menguji pengaruh negatif pengungkapan risiko terhadap asimetri informasi dan menguji peran fungsi internal audit dan spesialisasi auditor dalam memperkuat pengaruh negatif pengungkapan risiko terhadap asimetri informasi. Sampel penelitian terdiri dari 281 perusahaan yang terdaftar di Bursa Efek Indonesia (BEI) tahun 2016. Metode analisis yang digunakan dalam penelitian ini adalah metode analisis regresi moderasi dengan menggunakan alat analisis STATA Versi 13. Hasil penelitian menunjukkan bahwa pengungkapan risiko berpengaruh negatif dan signifikan terhadap asimetri informasi, sedangkan fungsi internal audit dan spesialisasi auditor tidak dapat memperkuat pengaruh negatif pengungkapan risiko terhadap asimetri informasi.
\end{abstract}

Kata Kunci: pengungkapan risiko, asimetri informasi, fungsi internal audit, spesialisasi auditor.

\section{Pendahuluan}

Pemisahan kepemilikan dan pengendalian dalam organisasi dapat menimbulkan masalah yaitu munculnya asimetri informasi antara pemegang saham dan manajer yang mengekspos pemegang saham atas biaya agensi. Biaya agensi timbul ketika para manajer memiliki insentif untuk memenuhi kepentingan mereka sendiri atas biaya yang ditanggung oleh pemegang saham (Jensen and Meckling, 1976). Biaya agensi juga timbul ketika investor tidak dapat membedakan nilai ekonomi sebenarnya dari perusahaan. Kurangnya informasi keuangan yang transparan menimbulkan risiko informasi yang lebih besar yang dibebankan kepada pemegang saham (Ashbaugh-Skaife et al., 2007). Hal ini mempengaruhi kepercayaan investor dan regulator terhadap informasi didalam laporan keuangan perusahaan. Ditambah dengan adanya globalisasi yang terus berkembang dan meningkatnya kompleksitas dalam transaksi bisnis menyebabkan investor dan regulator semakin menginginkan pengungkapan informasi tambahan selain data keuangan yaitu salah satunya adalah pengungkapan manajemen risiko oleh perusahaan (Meliani \& Hermawan, 2014). 
Dalam beberapa tahun terakhir, banyak perusahaan yang memberikan perhatian lebih terkait dengan manajemen risiko. Perusahaan memandang manajemen risiko sebagai sarana untuk meningkatkan kemungkinan keberhasilan dalam aktivitas perusahaan yang semakin kompleks, multi fungsi dan menantang (Olechowski et al., 2016). Dalam praktiknya, banyak manajer perusahaan yang telah menerapkan manajemen risiko, dan melaporkan risiko-risiko yang dihadapi oleh perusahaan. Hal ini dikarenakan pelaporan risiko dapat membantu investor untuk mengukur profil risiko perusahaan dan memungkinkan mereka untuk berinvestasi sesuai dengan toleransi risiko. Peraturan mengenai risiko dirancang untuk memperbaiki transparansi informasi bagi investor dan analis agar dapat mengurangi distorsi pasar dan meningkatkan efisiensi pasar modal (Abraham dan Marston, 2012).

Miihkinen (2013) dan Meliani \& Hermawan (2014) menemukan bahwa pengungkapan risiko dapat menurunkan tingkat asimetri informasi. Konsep asimetri informasi sudah sangat berkembang dalam literature, namun hanya sedikit bukti empiris yang mendukung keberadaannya (Sabet dan Heaney, 2015). Selain itu, topik mengenai manajemen risiko telah banyak diteliti, namun hanya sedikit peneliti yang memberikan wawasan mengenai pelaksanaan aktual manajemen risiko dalam praktik (Lyons dan Skitmore, 2004).

Penelitian baru-baru yang dilakukan oleh Bowers dan Khorakian (2014) juga menyatakan hal serupa bahwa sampai saat ini masih sedikit bukti mengenai keberhasilan penerapan manajemen risiko di negara-negara berkembang, termasuk salah satunya adalah Indonesia. Manajemen risiko di Indonesia tidak diterapkan secara jitu oleh perusahaan yang termasuk dalam sektor manufaktur sehingga menyebabkan sektor tersebut tidak berkembang dengan baik, padahal untuk menciptakan sektor manufaktur yang canggih tidak dapat dilepaskan dari penerapan manajemen risiko (Daruri, 2017, www.neraca.co.id). Hal ini diperparah dengan regulasi pengungkapan risiko di Indonesia yang masih terbatas. Sehingga, sejauh mana manfaat yang dapat diperoleh investor dari pengungkapan risiko untuk mengurangi asimetri informasi menjadi menarik untuk diteliti.

Fungsi Internal Audit (IA) dinilai memiliki peran yang potensial dalam pengelolaan risiko dan tata kelola perusahaan (Christopher et al., 2007). IA yang berkualitas tinggi dapat berfungsi sebagai pemantauan pihak ketiga atas tindakan manajemen setiap tahun (Prewitt et al., 2009). Agar fungsi IA dapat efektif dibutuhkan keahlian dan kompetensi (Lenz \& Hahn, 2015). Selain itu, fungsi IA yang efektif juga memiliki peran dan tanggung jawab yang cukup banyak dalam suatu perusahaan, salah satunya adalah terkait dengan manajemen risiko. IA harus memastikan kepada dewan mengenai risiko bisnis yang dihadapi perusahaan dan apakah manajemen risiko yang mereka kelola telah berjalan efektif. Manajemen perusahaan juga diharapkan tidak hanya menerbitkan laporan keuangan tradisional, tetapi juga dituntut untuk melaporkan kinerja non-keuangan karena laporan keuangan tradisional tidak dapat mewakili dimensi aktivitas perusahaan secara keseluruhan (Simnett, et al., 2009). Hal ini berarti bahwa terdapat informasi yang tidak diungkapkan secara publik. Salah satu laporan non-keuangan adalah laporan mengenai manajemen risiko. Glaum et al. (2013) menyatakan bahwa pengungkapan kinerja nonkeuangan perusahaan dapat meningkatkan keakuratan informasi dan menurunkan asimetri informasi.

Selain usaha yang dilakukan manajemen untuk meminimalisir asimetri informasi dengan mengelola risiko dan membentuk fungsi internal audit yang efektif, investor juga memerlukan pihak yang independen dan kompeten yang 
dapat memberikan keyakinan memadai atas informasi tersebut, salah satunya adalah jasa audit yang diberikan oleh Kantor Akuntan Publik (KAP) yang independen (Primadita \& Fitriany, 2012). Almutairi, et al. (2009) menyatakan bahwa audit merupakan salah satu cara untuk mengurangi asimetri informasi dan berkaitan dengan biaya agensi. Kualitas audit yang tinggi cenderung dapat mendeteksi dan menghindari kesalahan akuntansi daripada audit yang berkualitas rendah, sehingga audit yang berkualitas tinggi seharusnya lebih memungkinkan untuk mengurangi asimetri informasi.

Namun, terdapat asimetri informasi antara perusahaan klien dan auditor dalam proses auditing. Karyawan dan manajer perusahaan memiliki informasi yang lebih jelas mengenai struktur dan operasinya. Auditor adalah pihak ketiga yang mencoba memverifikasi informasi yang diberikan oleh manajemen perusahaan dengan skeptisisme profesional, yang mengharuskan auditor untuk bertindak dengan mempertimbangkan bahwa informasi yang diberikan oleh manajemen mungkin tidak akurat dan tidak reliable. Dalam hal ini, laporan keuangan yang diaudit sangat penting terutama bagi pihak ketiga karena dapat memberikan informasi yang tepat dan memungkinkan pengungkapan informasi yang harus diungkapkan. Oleh karena itu, opini auditor dan kualitas atas opini ini sangat penting (Varici, 2013).

Fokus utama penelitian ini adalah pada hubungan antara manajemen risiko, asimetri informasi, dan kualitas audit (baik fungsi internal auditor maupun eksternal auditor). Beberapa penelitian sebelumnya telah menemukan bahwa spesialisasi auditor membantu mengurangi asimetri informasi (contohnya: Hakim \& Omri, 2008; Almutairi et al., 2009; Primadita \& Fitriany, 2012; Cheong dan Zurbruegg, 2015). Namun, penelitian yang dilakukan oleh Varici (2013) yang menguji perusahaan publik di Turki menunjukkan hasil yang bertentangan yaitu bahwa
KAP big 4 justru memiliki kualitas audit yang lebih buruk dibandingkan KAP non big 4 dan menyebabkan asimetri informasi semakin besar. Penelitian tentang peran fungsi internal audit dan auditor eksternal dalam pengelolaan risiko perusahaan untuk dapat mengurangi asimetri informasi masih sangat terbatas, terutama di Indonesia sehingga hal ini menjadi relevan dan menarik untuk diteliti.

Bid-ask spread dapat mencerminkan tingkat asimetri informasi (Callahan et al., 2007). Harris (2003) menyatakan indikator bid-ask spread adalah selisih antara harga ask (kerelaan menjual) terendah dan harga bid (kerelaan membeli) tertinggi dari suatu instrumen keuangan. Tingkat bid-ask spread ditentukan oleh dealer sebagai kompensasi atas order processing cost (biaya mengatur dan mencatat transaksi), transaction cost (kompensasi atas biaya normal berbisnis untuk mendanai seluruh monopoli profit dan premi risiko) serta adverse selection cost (kompensasi atas potensi kerugian ketika berhadapan dengan informed traders). Semakin besar tingkat asimetri informasi, maka dealer akan berusaha untuk melindungi diri melalui peningkatan spread antara harga bid dan ask.

Dalam kaitannya dengan Corporate Governance (tata kelola perusahaan), tata kelola yang baik di perusahaan publik terutama di mana pemegang saham memiliki risiko tinggi untuk kehilangan aset mereka dapat mengurangi asimetri informasi antara pemegang saham dan manajemen. Prinsip pengungkapan publik, yang merupakan keharusan tata kelola perusahaan, ditujukan untuk mengurangi asimetri informasi (Varici, 2013). Keberadaan dewan komisaris merupakan sebuah mekanisme pengawasan dan arahan bagi tata kelola perusahaan. Allegrini dan Greco (2013) berpendapat dewan komisaris yang efektif dapat memitigasi konflik kepentingan dan asimetri informasi. Komite audit juga berperan sebagai pengawas serta 
berperan mensupervisi laporan keuangan. komite audit yang efektif dapat menambah pengungkapan informasi tentang proyeksi perusahaan dan risiko (Allegrini dan Greco, 2013) dan menambah kesempatan mendeteksi manipulasi laporan keuangan (Garcia et al., 2012). Desender (2007) berpendapat bahwa manajemen risiko telah berevolusi dari pandangan asuransi berbasis sempit menjadi lebih holistic. Pada bulan September 2004, Komite Sponsoring Organisasi Komisi Treadway (COSO) mengeluarkan Enterprise Risk Management-Integrated Framework, untuk menyediakan kerangka model untuk manajemen risiko perusahaan (ERM). Risiko dapat diartikan ketidakpastian atas jumlah manfaat yang akan diterima, termasuk potensi keuntungan serta ancama kerugian. Menurut Florio \& Leoni (2017), ada enam komponen sistem ERM yang dapat berkontribusi pada kecanggihan ERM yaitu keberadaan CRO, Komite Risiko, Laporan Manajemen Risiko yang dilaporkan ke Dewan Direksi, serta frekuensi, level, dan metode penilaian risiko. Mempelajari proksi ERM secara terpisah sangat membantu untuk menganalisis kontribusi tunggal komponen tersebut, namun gagal dalam mendeteksi efek keseluruhan komponenkomponen tersebut. Oleh karena itu, untuk menangkap implikasi ERM holistik di mana sistem Manajemen Risiko yang terintegrasi, Florio \& Leoni (2017) menggabungkan enam aspek dalam skor ERM. Perusahaan dengan komitmen tinggi akan memperoleh penghematan biaya (Farrell \& Gallagher, 2014), termasuk biaya agensi atas asimetri informasi.

The Institute of Internal Auditor (IIA) mendefinisikan audit internal sebagai kegiatan assurance dan konsultasi independen yang bertujuan untuk memberi nilai tambah dan memperbaiki operasi organisasi. Aktivitas audit internal ini dapat membantu organisasi untuk mencapai tujuannya dengan menerapkan pendekatan yang sistematis dan disiplin untuk mengevaluasi dan memperbaiki manajemen risiko, pengendalian, dan proses tata kelola. Aktivitas audit internal dilaksanakan oleh Internal Audit (IA). IA merupakan auditor yang bekerja dalam sebuah organisasi untuk menentukan apakah prosedur dan kebijakan telah dipatuhi, apakah penjagaan atas aset perusahaan telah berjalan dengan baik, apakah aktivitas kegiatan perusahaan telah efektif dan efisien dan menentukan keandalan informasi yang dihasilkan (Mulyadi, 2002).

Ridley (2008) menyebutkan bahwa IA modern dibangun "3E" yaitu Efektivitas, Efisiensi, dan Ekonomi. Efektivitas dipandang sebagai "doing the right thing", efisiensi berarti "doing them well", dan ekonomi berarti "doing them cheaply" (Chamber, 1992). IA yang berkualitas harus bisa melaksanakan fungsinya dengan menerapkan $3 \mathrm{E}$ tersebut. Untuk bisa mencapai 3E, maka IA harus ditunjang dengan keahlian yang dapat mendukung fungsinya tersebut seperti sertifikasi, pengalaman, kompetensi dan lain sebagainya (Prawitt, 2009).

Struktur keuangan dan hasil usaha perusahaan penting terutama bagi pemegang saham dan kreditur, namun pihak-pihak ini tidak memiliki kemungkinan untuk mendapatkan informasi langsung. Keakuratan dan keandalan informasi atas keuangan perusahaan sama pentingnya dengan mencapainya. Audit independen diperlukan untuk memberikan keyakinan atas keandalan informasi tersebut sehingga dapat mencegah kemungkinan konflik kepentingan diantara para manajer dan pemegang saham. Namun, menurut Kavut (2001), manfaat yang diharapkan dapat diperoleh dari audit independen hanya jika layanan audit berkualitas tinggi diberikan. 


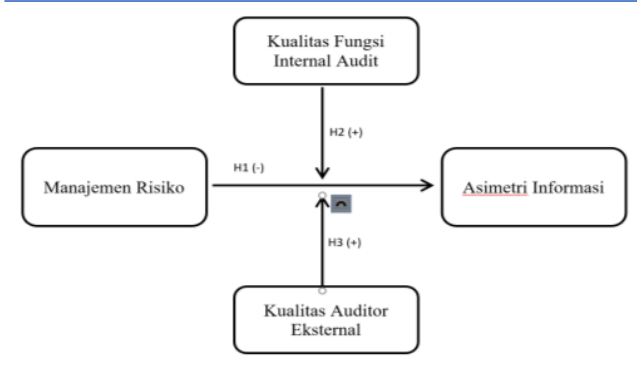

\section{Metode Penelitian}

Penelitian ini merupakan studi empiris kuantitatif. Penelitian ini melakukan pengujian regresi atas penerapan ERM (Enterprise Risk Management) terhadap Asimetris Informasi, Kualitas Audit, dan Fungsi Internal Audit. Populasi yang digunakan pada penelitian ini adalah seluruh perusahaan non keuangan dan non asuransi yang terdaftar di BEI pada tahun 2016. Pemilihan sampel dilakukan dengan cara purposive sampling, yaitu teknik penentuan sampel dengan pertimbangan tertentu (Gujarati, 2004).

\section{Model Penelitian:}

BTBit $=\beta_{0}+\beta 1$ RISKDISCit + $\beta 2$ SPECAUDit $+\beta 3$ IA_SCOREit + $\beta 4 R I S K D I S C i t * S P E C A U D i t$

$\beta 5$ RISKDISCit*IA_SCOREit $+\beta 6$ SIZEit $+\beta 7$ AGEit $+\beta 8$ ROAit $+\beta 9$ LifeCycleit + cit ........ Persamaan 1

Tabel 1, Deskripsi Variabel Dalam Model

\begin{tabular}{|l|l|}
\hline Variabel & Deskripsi \\
\hline MTB & Market to book value \\
\hline$\beta_{0}$ & $\begin{array}{l}\text { Intercept setiap } \\
\text { persamaan regresi }\end{array}$ \\
\hline$\beta_{1}, \ldots, \beta_{\mathrm{n}}$ & $\begin{array}{l}\text { Koefisien regresi } \\
\text { variabel independen }\end{array}$ \\
\hline RISKDISCit & $\begin{array}{l}\text { Tingkat } \\
\text { pengungkapan risiko }\end{array}$ \\
\hline SPECAUDit & $\begin{array}{l}\text { Bernilai 1 untuk } \\
\text { perusahaan yang } \\
\text { diaudit oleh auditor } \\
\text { spesialis dan 0 apabila } \\
\text { sebaliknya }\end{array}$ \\
\hline IAC_Experience & $\begin{array}{l}\text { Jumlah tahun lama } \\
\text { bekerja menjadi } \\
\text { Internal Audit Chief } \\
\text { (Kepala Fungsi }\end{array}$ \\
\hline
\end{tabular}

\begin{tabular}{|c|c|}
\hline Variabel & Deskripsi \\
\hline & Internal Audit) \\
\hline IA_Certification & $\begin{array}{l}\text { Bernilai 1 jika kepala } \\
\text { fungsi internal audit } \\
\text { memiliki sertifikasi } \\
\text { IA, dan } 0 \text { apabila } \\
\text { sebaliknya }\end{array}$ \\
\hline IA_Background & \begin{tabular}{lr}
\multicolumn{3}{l}{ Bernilai 1 jika kepala } \\
fungsi internal audit \\
memiliki & latar \\
belakang & akuntansi, \\
dan 0 0 & apabila \\
sebaliknya &
\end{tabular} \\
\hline IA Charter & $\begin{array}{l}\text { Bernilai } 1 \text { jika } \\
\text { terdapat piagam } \\
\text { internal audit, dan } 0 \\
\text { apabila sebaliknya }\end{array}$ \\
\hline IA_Training & $\begin{array}{l}\text { Bernilai } 1 \text { jika } \\
\text { terdapat pelatihan } \\
\text { untuk IA, dan } 0 \\
\text { apabila sebaliknya }\end{array}$ \\
\hline IA_SCOREit & $\begin{array}{l}\text { Jumlah skor total } \\
\text { IAC_Experience, } \\
\text { IA_Certification, } \\
\text { IA_Background, IA } \\
\text { Charter, } \\
\text { IA_Training }\end{array}$ \\
\hline SIZEit & $\begin{array}{l}\text { Logaritma natural dari } \\
\text { total aset }\end{array}$ \\
\hline Eit & Koefisien Error \\
\hline
\end{tabular}

Untuk mengkontrol model hubungan kualitas audit dan asimetri informasi, penelitian ini mengkontrol ukuran perusahaan yang diukur oleh logaritma dari total asset yang dimiliki oleh perusahaan sebagai karakteristik perusahaan (Simunic 1980; Pratt dan Stice 1994; Simunic dan Stein 1996; Hay et al. 2006; DeAngelo et al. 2006; Eshleman dan Guo 2013). Teknik analisis yang digunakan adalah dengan content analysis untuk memperoleh nilai pengungkapan ERM yang dibantu dengan Nvivo 11 serta analisis regresi data panel dengan pendekatan unbalanced panel data dengan software Stata 12.

\section{Hasil dan Pembahasan}


Setelah menentukan sampel penelitian dan mengumpulkan data yang dibutuhkan, selanjutnya dilakukan pengujian seperti yang telah dipaparkan pada Metdologi Penelitian dalam penelitian ini. Berikut diuraikan hasil atas pengujian-pengujian yang telah dilakukan.

Tabel 2. Statistik Deskriptif Variabel

\begin{tabular}{lccccc}
\hline Variable & Obs & Mean & $\begin{array}{c}\text { Std. } \\
\text { Dev. }\end{array}$ & Min & Max \\
\hline BAS & 281 & 2,86 & 2,61 & 0,25 & 9,99 \\
ERM_Score & 281 & 1,80 & 1,57 & 0,00 & 6,00 \\
AUDSPES & 281 & 0,44 & 0,50 & 0,00 & 1,00 \\
IAScore & 281 & 2,21 & 1,15 & 0,00 & 4,00 \\
Asset (billion) & 281 & 8,77 & 20,3 & 13.2 & 262
\end{tabular}

Tabel 3. Hasil Pengujian Model Regresi

Variabel Dependen: BAS

\begin{tabular}{ccccc}
\hline \multirow{2}{*}{ Variabel } & \multicolumn{2}{c}{ Model 1 } & \multicolumn{2}{c}{ Model 2 } \\
\cline { 2 - 5 } & Coef. & Sig. & Coef. & Sig. \\
\hline C & 22.1576 & 0,000 & & \\
\hline ERM_Socre & -0.6417 & 0,023 & 0.0565 & 0.884 \\
& & ${ }^{* * *}$ & & \\
\hline AUDSPES & -0.4347 & 0,500 & & \\
\hline ERM*AUDSPES & 0.6393 & 0.137 & & 0.187 \\
\hline IAScore & & & 0.3243 & 0 \\
\hline ERM*IAScore & & & -0.1744 & 0,234 \\
\hline SIZE & -0.6525 & 0.000 & -0.0873 & $0,000^{*}$ \\
& & & & ${ }^{* * * *}$ \\
\hline Prob. F & 0,0000 & 0,0000 \\
\hline R-squared & 0,1710 & 0,1669 \\
\hline $\mathrm{N}$ & 281 & \multicolumn{2}{c}{281} \\
\hline
\end{tabular}

Model 1 dalam tabel 3.. merupakan model pengujian regresi untuk mengetahui pengaruh penungkapan ERM terhadap asimetri informasi dan peran auditor eksternal dalam memperkuat pengaruh tersebut. Berdasarkan Tabel 3 Model 1 dapat dilihat bahwa secara keseluruhan model ini sudah cukup bagus yaitu ditunjukan dengan nilai uji $F$ yang signifikan dibawah 1 persen dengan nilai R-squared nya sebesar 0,1710 yang artinya model ini dapat menjelaskan variasi dari asimetri informasi perusahaan sebesar 17,10 persen.
Berdasarkan tabel 3 Variabel ERM memiliki nilai signifikansi sebesar 0,023 $<\alpha(5 \%)$ dan hubungannya negatif, sehingga H1 diterima. Hal ini berarti bahwa pengungkapan manajemen risiko yang dilakukan perusahaan dapat mengurangi asimetri informasi. Hasil penelitian ini mendukung penelitian yang dilakukan oleh Campbell et al., (2014) dan Miihkinen (2013). Penelitian yang dilakukan oleh Campbell menunjukkan hasil bahwa pengungkapan risiko berhubungan negatif dan signifikan dengan tingkat asimetri perusahaan yang diproksikan dengan bid-ask spread. Hal ini karena pengungkapan risiko yang dilakukan oleh manajer perusahaan berisi 
informasi yang bermanfaat bagi partisipan pasar karena informasi tersebut menggambarkan risiko-risiko apa saja yang dihadapi perusahaan. Sehingga, informasi tersebut dapat dijadikan sebagai bahan pertimbangan investor dalam menilai perusahan. Hasil serupa juga ditunjukkan dalam penelitian Miihkinen (2013) yaitu bahwa pengungkapan risiko yang berkualitas tinggi dapat mengurangi asimetri informasi di pasar saham karena informasi mengenai pengungkapan risiko dapat bermanfaat bagi investor. Hal ini dikarenakan informasi mengenai risiko dapat mempengaruhi keputusan investasi seorang investor.

Peran moderasi dari auditor eksternal menunjukkan nilai signifikansi sebesar $0,147>\alpha$ sehingga $\mathrm{H} 2$ dalam penelitian ini tidak dapat diterima. Hal ini berarti bahwa auditor esksternal tidak dapat memperkuat hubungan negatif pengungkapan risiko terhadap asimetri informasi. Penelitian yang dilakukan oleh Varici (2013) menunjukkan hasil yang bertentangan dengan literature. Secara teori, perusahaan yang diaudit oleh KAP spesialis diharapkan dapat memberikan layanan audit yang berkualitas tinggi sehingga dapat mengurangi asimetri informasi. Namun, terdapat kekhawatiran bahwa KAP non spesialis mungkin juga dapat memberikan layanan audit dengan kualitas yang tidak lebih rendah dari KAP spesialis (Varici, 2013). Dapat disimpulkan bahwa spesialisasi auditor tidak dapat memperkuat pengaruh negatif pengungkapan risiko terhadap asimetri informasi. Hal ini dikarenakan bahwa tidak dapat dipastikan apakah auditor eksternal yang bukan spesialis tidak dapat mengurangi asimetri informasi. Berdasarkan statistik deskriptif dalam penelitian ini menunjukkan nilai rata-rata spesialisasi auditor hanya sebesar $44 \%$, yang berarti bahwa setengahnya yaitu 56\% dari sampel penelitian diaudit oleh auditor yang bukan spesialis. Penelitian selanjutnya mungkin dapat menguji peran auditor eksternal yang bukan spesialisasi terhadap asimetri informasi.
Model 2 merupakan model pengujian regresi untuk mengetahui pengaruh penungkapan ERM terhadap asimetri informasi dan peran fungsi internal audit dalam menguatkan pengaruh tersebut. Berdasarkan Tabel 3. Model 2 dapat dilihat bahwa secara keseluruah model ini sudah cukup bagus yaitu ditunjukan dengan nilai uji $F$ yang signifikan dibawah 1 persen dengan nilai R-squared nya sebesar 0,1669 yang artinya model ini dapat menjelaskan variasi dari asimetri informasi perusahaan sebesar 16,69 persen.

Jika dilihat dari hasil regresi model 2, koefisien variabel pengungkapan ERM (ERM_Score) menunjukan nilai positif dan tidak signifikan $(0,565)$. Selain itu, arah koefisien tersebut juga berlawanan dengan hipotesis yang diajukan. Penemuan ini berbeda seperti hasil yang ditemukan dalam model 1, dan juga berbeda dengan penelitian sebelumnya seperti penelitian Campbell et al. (2014) yang menemukan pengaruh negatif pengungkapan ERM yang berkualitas terhadap asimetri informasi. Ini menunjukan model ini tidak mendukung gagasan yang menyatakan bahwa pengungkapan ERM dapat berpengaruh negatif terhadap asimetri informasi.

Begitu juga dengan koefisien variabel moderasinya yaitu fungsi internal audit (IAScore) dan interaksi antara pengungkapan ERM dengan fungsi internal audit (ERM*IAScore) yang menunjukan nilai signifikansi diatas 10 persen. Berdasarkan hasil regresi ini maka penelitian ini menolak hipotesis 2 dan Hipotesis 3. Artinya, fungsi internal audit tidak memiliki pengaruh terhadap asimetri informasi, dan juga tidak memperkuat pengaruh negatif pengungkapan ERM terhadap asimetri informasi. Berdasarkan analisis kami, kurangnya informasi tentang karakteristik fungsi internal audit yang diungkapkan perusahaan dalam laporan keuangan membuat hasil skoring menjadi kurang valid. Hal ini disebabkan banyaknya perusahaan yang tidak mengungkapkan karakteristik fungsi intenal audit nya secara rinci. Sehingga nilai skor dari 
fungsi internal audit yang didapat tidak merepresentasikan sepenuhnya efektiftas pengawasan yang dilakukan oleh fungsi internal audit perusahaan.

\section{Simpulan}

Penelitian ini bertujuan untuk menguji pengaruh pengungkapan ERM terhadap tingkat asimetri informasi, dan menguji apakah kualitas audit eksternal dan fungsi internal audit dapat memperkuat pengaruh tersebut. Sampel yang digunakan adalah perusahaan non keuangan dan bank yang terdaftar di BEI pada periode tahun 2016. Pengungkapan ERM diukur dengan konten analisis menggunakan 6 kriteria yaitu keberadaan CRO, komite risiko, mekanis laporan langsung pengawasan hasil risiko kepada board, frekuensi penilaian risiko, level penilaian risiko, dan metode penilaian risiko. Untuk mengukur asimetri informasi digunakan nilai bid ask spread, kualitas auditor eksternal menggunakan spesialis auditor, dan internal audit menggunakan skoring fungsi internal audit berdasarkan laporan tahunan perusahaan.

Berdasarkan hasil konten analisis menunjukan pengungkapan ERM diperusahaan non keuangan dan bank masih berada di level rendah yaitu dengan rata-rata 1,8 dari total skor ratarata 6. Hasil analisis regresi menunjukan bahwa pengungkapan ERM tidak sepenuhnya berpengaruh terhadap asimetri informasi. Pengungkapan ERM berpengaruh terhadap asimetri informasi pada kondisi dimana kualitas auditor eksternalnya tinggi yang ditunjukan melalui auditor spesialis dalam bidang nya. Oleh karena itu, penelitian ini mengkonfirmasi bahwa kualitas auditor spesialis berperan memperkuat pengaruh pengungkapan ERM dalam menurunkan asimetri informasi. Namun, terkait penelitian ini tidak menemukan bukti yang cukup bahwa kualitas fungsi internal audit dapat memoderasi pengaruh pengungkapan ERM terhadap asimetri informasi. Masih kurang nya informasi yang disajikan perusahaan terkait fungsi internal audit nya menjadi kendala dalam menilai efektifitas pengawasan yang dilakukan internal audit terhadap aktivitas manajemen.

\section{Daftar Pustaka}

Abdolmohammadi, M., \& Wright, A. (1987). An examination of the effects of experience and task complexity on audit judgments. The Accounting Review, 1-13.

Abraham, S., Marston, C., \& Darby, P. (2012). Risk reporting: Clarity, relevance and location. Institute of Chartered Accountants of Scotland.

Allegrini, M., \& Greco, G. (2013). Corporate boards, audit committees and voluntary disclosure: Evidence from Italian listed companies. Journal of Management Governance, 17(1), 187-216.

Almutairi, A. R., Dunn, K. A., \& Skantz, T. (2009). Auditor tenure, auditor specialization, and information asymmetry. Managerial Auditing Journal, 24(7), 600-6123.

Ashbaugh-Skaife, H., Collins, D. W., \& Kinney, W. R. (2007). The discovery and reporting of internal control deficiencies prior to SOXmandated audits. Journal of Accounting and Economics, 44(1), 166-192.

Balsam, S., Krishnan, J., \& Yang, J. S. (2003). Auditor industry specialization and earnings quality. Auditing: A journal of practice \& Theory, 22(2), 71-97.

Bowers, J. dan Khorakian, A. (2014). Integrating risk management in the innovation project. European Journal of Innovation Management, Vol. 17 (1), pp.2540

Callahan CM, Lee CMC, Yohn TL. 1997. Accounting information and bid-ask spreads. Accounting Horizons 11(4): 50-60.

Campbell, J.L., Chen, H., Dhaliwal, D.S., Lu, H., dan Steele, L.B. (2014). 
The Information Content of Mandatory Risk Factor Disclosures in Corporate Filings. Rev Account Stud, Vol. 19, pp. 396-455

Chambers, A. D. (1992). Effective Internal Audits: How to plan and implement. Financial Times.

Cheong, C., \& Zurbruegg, R. (2015). Analyst forecasts, firm asymmetric information and audit quality.

Christopher, J., Leung, P., \& Sarens, G. (2007, January). An exploratory study on internal audit independence in Australia. In AFAANZ 2007: accounting and finance association of Australia and New Zealand annual conference. The Accounting and Finance Association of Australia and New Zealand.

Craswell, A., Stokes, D. J., \& Laughton, J. (2002). Auditor independence and fee dependence. Journal of Accounting and Economics, 33(2), 253-275.

Daruri, A. D. (2017). Sektor Manufaktur dan Manajemen Risiko. http://www.neraca.co.id/article/ 92907/sektor-manufaktur-danmanajemen-risiko

DeAngelo, H., DeAngelo, L., dan Stulz, R.M. (2006). Dividend policy and the earned/contributed capital mix: a test of the life-cycle theory. Journal of Financial Economics, Vol. 81, pp. 227-254

Eshleman, J. D., \& Guo, P. (2013). Abnormal audit fees and audit quality: The importance of considering managerial incentives in tests of earnings management. Auditing: A Journal of Practice \& Theory, 33(1), 117 138.

Farrell, M., \& Gallagher, R. (2015). The valuation implications of enterprise risk management maturity. Journal of Risk and Insurance, 82(3), 625-657.

Florio, C., \& Leoni, G. (2017). Enterprise risk management and firm performance: The Italian case. The
British Accounting Review, 49(1), 56-74.

García, L. S., Barbadillo, E. R., \& Pérez, M. O. (2012). Audit committee and internal audit and the quality of earnings: empirical evidence from Spanish companies. Journal of Management \& Governance, 16(2), 305-331.

Getie Mihret, D., James, K., \& Mula, J. M. (2010). Antecedents and organisational performance implications of internal audit effectiveness: some propositions and research agenda. Pacific Accounting Review, 22(3), 224252.

Glaum, M., Schmidt, P., Street, D. L., \& Vogel, S. (2013). Compliance with IFRS 3-and IAS 36-required disclosures across 17 European countries: company-and countrylevel determinants. Accounting and business research, 43(3), 163-204.

Gujarati, D., \& Porter, D. C. (2009). Basic econometrics (ed.) McGrawHill.

Hakim, F., Triki, F., \& Omri, A. (2008). Earnings quality and equity liquidity: evidence from Tunisia. International Journal of Managerial and Financial Accounting, 1(2), 147-165.

Harris, L. (2003). Trading and exchanges: Market microstructure for practitioners. Oxford University Press, USA.

Hay, D., Knechel, R., \& Li, V. (2006). Non-audit Services and Auditor Independence: New Zealand Evidence. Journal of Business Finance \& Accounting, 33(5-6), 715-734.

Jensen, M. C. dan Meckling. W. H. (1976). Thery of The Firm: Managerial Behavior, Agency Cost, and Ownership Structure. Jurnal of Financial Economics, Vol. 3 (4), pp. 305-360

Kavut, L. (2001). Opinions and Attitudes of Independent Auditors and Users of Audit Services Concerning 
Audit Quality. Istanbul Stock Exchange Review, 5(20), 1-30.

Lenz, R., \& Hahn, U. (2015). A synthesis of empirical internal audit effectiveness literature pointing to new research

opportunities. Managerial

Auditing Journal, 30(1), 5-33.

Leuz, C., \& Verrecchia, R. E. (2000). The economic consequences of increased disclosure. Journal of accounting research, 91-124.

Lev, B. (1988). Towards a theory of equitable and efficient accounting policy. The Accounting Review, 63 (1), 1-22.

Lyons, T. dan Skitmore, M. (2004). Project risk management in the Queensland engineering construction industry: a survey. International Journal of Project Management, Vol. 22, pp. 51-61

Megginson, W. L. (1997). Corporate finance theory. Addison-Wesley.

Meliani, Ester G. Hermawan, Ancella A. 2014. Pengaruh tingkat pengungkapan risiko terhadap informasi asimetri dengan efektivitas dewan komisaris dan komite audit serta siklus hidup perusahaan sebagai variabel pemoderasi. Universitas Indonesia.

Miihkinen, A. (2013). The usefulness of firm risk disclosures under different firm riskiness, investorinterest, and market conditions: New evidence from Finland. Advances in Accounting, 29(2), 312-331.

Mina, Pizzina. (2012). Impact of internal audit function quality and contribution on audit delays. Calhoun: The NPS Institutional Archive DSpace Repository, http://hdl.handle.net/10945/47547

Mubarok, M. A., \& Rohman, A. (2013). Pengaruh Karakteristik Perusahaan Dan Mekanisme Corporate Governance Terhadap Pengungkapan Risiko Dalam Laporan Keuangan Interim (Studi Empiris Pada PerusahaanPerusahaan Nonkeuangan Yang
Terdaftar Di Bursa Efek Indonesia) (Doctoral Dissertation, Fakultas Ekonomika Dan Bisnis).

Mulyadi, K. P. (2002). Auditing. Penerbit Salemba Empat. Jakarta.

Olechowski, A., Oehmen, J., Seering, W., dan Ben-Daya, M. (2016). The professionalization of risk management: What role can the ISO 31000 risk management principles play?. International Journal of Project Management, Vol. 34, pp. 1568-1578

Paape, L. (2007). Corporate governance: The impact on the role, position, and scope of services of the internal audit function.

Pratt, J., \& Stice, J. D. (1994). The effects of client characteristics on auditor litigation risk judgments, required audit evidence, and recommended audit fees. Accounting Review, 639-656.

Prawitt, D. F., Smith, J. L., \& Wood, D. A. (2009). Internal audit quality and earnings management. The Accounting Review, 84(4), 12551280.

Prewitt, J. E., Weil, R., \& McClure, A. Q. (2011). Crisis Leadership-An Organizational

Opportunity. Australian Journal of Business and Management Research, 1(6), 60.

Primadita, I. Fitriany. 2012. Pengaruh tenure audit dan auditor spesialis terhadap informasi asimetri. Simposium Nasional Akuntansi XV.

Reichelt, K. J., \& Wang, D. (2010). National and office-specific measures of auditor industry expertise and effects on audit quality. Journal of Accounting Research, 48(3), 647-686.

Ridley, J. (2008), Cutting Edge Internal Auditing, John Wiley \& Sons, Ltd, Chichester, England.

Sabet, A. H. dan Heaney, R. (2015). Bidask spread, information asymmetry and acquisition of oiland gas assets. Journal of International 
Financial Markets, Institutions \& Money, Vol. 37, pp. 77-84

Scott, W.R., 2015. Financial Accounting Theory. 7th Edition. Prentice Hall.

Simnett, R., Vanstraelen, A., \& Chua, W. F. (2009). Assurance on sustainability reports: An international comparison. The accounting review, 84(3), 937-967.

Simunic, D. A. (1980). The pricing of audit services: Theory and evidence. Journal of accounting research, 161-190.
Simunic, D. A., \& Stein, M. T. (1996). Impact of litigation risk on audit pricing: A review of the economics and the evidence. Auditing, 15, 119.

Varici, I. (2013). The Relationship between Information Asymmetry and the Quality of Audit: An Empirical Study in Istanbul Stock Exchange. International Business Research, 6(10), 132. 